\title{
Spectrophotometric Determination of Sulfamethoxazole in Pure and in Pharmaceutical Preparations by Diazotization and Coupling Reaction
}

\author{
Salim A. Mohammed \\ Nassem M. Al-Hamdany \\ Asmaa N. Abdulkader \\ Department of Chemistry/ College of Science/ University of Mosul
}

(Received 6/6/2018 ; Accepted 3/12/2018)

\begin{abstract}
A highly sensitive, simple and accurate spectrophotometric method has been developed for quantitative determination of sulfamethoxazole(SMX) in both pure form and pharmaceutical preparations. In this method SMX is diazotized with equimolar of sodium nitrite $\left(\mathrm{NaNO}_{2}\right)$ in acid medium of hydrochloric acid to form diazonium ion , which is reacted with 2,4,6-trihydroxybenzoic acid in alkaline medium of $\mathrm{NaOH}$ to form a yellow water soluble azo dye that has absorption maximum at $416 \mathrm{~nm}$ versus reagent blank. Beer's law is obeyed over the concentration range 0.2-16 $\mu \mathrm{g} . \mathrm{ml}^{-1}$ with an excellent determination coefficient $\left(\mathrm{r}^{2}=0.9996\right)$ and molar absorptivity $1.84 \times 10^{4}$ 1. $\mathrm{mol}^{-1} . \mathrm{cm}^{-1}$. The recoveries are obtained in the range of $97.8-99.8 \%$ and the relative standard deviation is better than $\pm 0.23 \%$. The stoichiometry of the resulting azo dye has been also worked out and it is found to be 1:1 SMX: 2,4,6-trihydroxybenzoic acid. This method has been applied successfully for the determination of SMX in pharmaceutical preparations (tablets and oral suspension).
\end{abstract}

Keywords: Sulfamethoxazole; Diazotization; 2,4,6-Trihydroxybenzoic acid; Spectrophotometry.

التقدير الطيفي للسلفاميثوكسازول بحالته النقية وفي المستحضرات الصيدلانية بوساطة الازوتة والاقتران

$$
\begin{aligned}
& \text { الملغص } \\
& \text { يتضمن البحث نطوير طريقة طيفية بسيطة و حساسة لنقدير كميات مايكروغرامية من السلفامينوكسازول بحالته النقية وفي } \\
& \text { المستحضرات الصيدلانية. تعتمد الطريقة على ازوتة السلفاميثوكسازول في وسط حامضي من حامض الهيدروكلوريك مع كمية } \\
& \text { متكافئة من نتريت الصوديوم لتكوين ايون الديازونيوم الذي يتفاعل مع كاثف 6,4,2- ثلاثي هيدروكسيل حامض البنزويك في }
\end{aligned}
$$

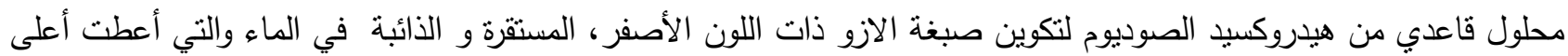

$$
\begin{aligned}
& \text { امتصاص عند الطول ألموجي } 416 \text { نانوميتز وكان مدى الخطية الذي ينطبق على قانون بير يقع ضمن مدى التركيز من }
\end{aligned}
$$

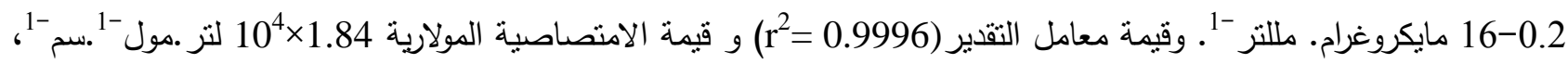

$$
\begin{aligned}
& \text { بينما تراوحت قيم نسبة الاسترجاع بين } 97.8 \text { و } 99.8 \text { \% بانحراف قياسي نسبي أفضل من ـ0.23 } 0.8 \text { وكانت النسبة التركيبية المولية } \\
& \text { بين السلفاميثوكسازول و الكاثف 6,4,2- ثلاثي هيدروكسيل حامض البنزويك 1:1، وقد طبقت الطريقة بنجاح لتقدير } \\
& \text { السلفاميثوكسازول على بعض المستحضرات الصيدلانية الحاوية على السلفاميثوكسازول في الأقراص الدوائية والمحلول المعلق. } \\
& \text { الكلمات الدالة: سلفاميثوكسازول، ازوتة واقتران، 6,4,2- ثلاثي هيدروكسيل حامض البنزويك، تقدير مطيافي. }
\end{aligned}
$$

\section{INTRODUCTION}

Sulfamethoxazole (SMX) is a sulfonamide bacteriostatic antibiotic that is a highly effective chemotherapeutic agent, which competitively inhibits the bacterial enzyme dihydropteroate synthetase (Mandel and Petri, 2006). Sulfonamides are structural analogs and competitive antagonists of para-aminobenzoic acid (PABA). They inhibit normal bacterial utilization of PABA 
for the synthesis of folic acid, an important metabolite in DNA synthesis (Mitscher, 2002). SMX is mostly marketed in combination with trimethoprim (TMP) as a co-trimazole dosage (Nazer et al., 2001). A combination of TMP/SMX is an effective antimicrobial agent that is commonly used in dairy cattle for the treatment or prevention of respiratory infections and mastitis (Bedor et al., 2008). SMX is short to medium acting agents used almost exclusively to treat urinary tract infections, eye infections and as a prophylaxis of rheumatic fever (Petri, 2001). It is commonly used to treat pneumoig, tuberculosis, mningitis and tonsillitis. SMX is white crystallized powder. It does not dissolve in ether and chloroform solvents. It has low solubility in water, but it dissolves in acetone $(1: 30)$ and in ethanol (1: 50). On the other hand, it dissolves in alkaline hydroxide solutions (Barragry, 1994). SMX is chemically known as [4-amino -N-(5-methylisoxazole-3-yl) benzenesulfonamide] Fig. (1).

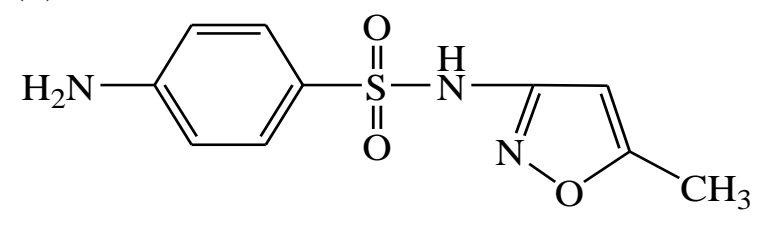

M.wt. $=253.28 \mathrm{~g} / \mathrm{mol}$

Fig. 1: The chemical structure of SMX

Several analytical techniques have been reported for determination of SMX in pharmaceutical formulations and biological fluids. Most of these techniques employed separation methods, such as solid phase extraction-liquid chromatography using an on line clean-up column coupled with amperometric detection employing a boron-doped diamond (BDD) electrode (Andrade et al., 2009), HPLC-tandem mass spectrometry (LC-MS/MS) (Mistri et al., 2010) or capillary electrophoresis (Qing-Cui et al., 2008). Other techniques such as differential pulse voltammetry (DPV) (Joseph and Kumar, 2010), square wave voltammetry (SWV) (Souza et al., 2008), micellar electrokinetic capillary chromatography (Injac et al., 2008), partial least square regression method (Givianrad et al., 2013), flow injection system /HPLC (Sabriye et al., 2011) and ratio derivative spectrophotometry (Hajian et al., 2010) have been also used for determination of SMX. Most of these techniques are time consuming and expensive, as well as the most potentiometric methods which are used SMX as ion-selective electrodes are either not readily available in the market or expensive.

Many spectrophotometric methods have been also used for the determination of SMX in pharmaceutical preparations. Most of them included diazotization reaction of SMX and coupling with different coupling agents such as phloroglucinol (Upadhyay et al., 2012 ), pyrogallol (Othman, 2005), 1-naphthol (Sinan and Al-Uzri, 2011), tropaeolin O (Boiko et al., 2011), $\gamma$-resorsolic acid (Mohammed and Zamel, 2017), 2-Naphthol (Shamsa and Amani, 2006) and diphenylamine (Khalaf et al., 2014). Other methods were either based on the charge transfer reaction with chloranilic acid to form complex (Adegoke et al., 2017), condensation reaction with 1,2-napthoquinone-4-sulphonic acid (Khalaf et al., 2017), Schiff's base reaction with p-dimethylaminobenzaldehyde (Siddappa et al., 2011) or oxidation-reduction reaction with ferric ions and potassium ferricyanide by using resorcinol as reagent (Vijaya et al., 2008). Some of these methods suffer from various limitations for example, low stability of the colored product formed and laborious (Adegoke et al., 2017). Others required heating, extraction (Upadhyay et al., 2012), applicable to higher concentrations of the drug (Shamsa and Amani, 2006) or long time for the reaction to complete (Siddappa et al., 2011), In the present study, a new coupling agent is employed to develop a simple, sensitive and inexpensive spectro-photometric method for the assay of SMX in both pure and in its dosage forms. The method is based on the diazotization reaction of SMX with equimolar of sodium nitrite in acid medium; the formed diazonium ion is then coupled with 2,4,6-trihydroxybenzoic acid in sodium hydroxide medium to form a yellow water soluble azo dye. This method does not need to get rid of 
excess sodium nitrite (by addition sulfamic acid or ammonium sulfamate) because of the low concentration of sodium nitrite used by adding equimolar solution of SMX and sodium nitrite.

\section{Apparatus}

\section{EXPERIMENTAL}

All absorption spectra and absorbance measurements are performed using a CECILL CE 7200 recording spectrophotometer with $1-\mathrm{cm}$ silica cells. The $\mathrm{pH}$ measurements are made with a professional TRANS BP 300.

\section{Reagents}

All experiments were performed with analytical - reagent grade chemicals.

SMX stock solution $(\mathbf{5 0 0} \boldsymbol{\mu g} / \mathbf{m l})$. Accurately weighed 0.05g of SMX (SDI-Iraq) was dissolved in $5 \mathrm{ml}$ of ethanol and the volume was completed to $100 \mathrm{ml}$ with distilled water. Working solution $\left(200 \mu \mathrm{g} / \mathrm{ml}=7.89 \times 10^{-4} \mathrm{M}\right)$ of SMX was prepared by diluting appropriate volume of the stock solution with distilled water.

2,4,6-Trihydroxybenzoic acid solution $(0.1 \%$ w/v). It was prepared by dissolving $0.1 \mathrm{~g}$ of 2,4,6trihydroxybenzoic acid provided by (Fluka) in distilled water and completed to the mark in $100 \mathrm{ml}$ calibrated flask. The solution was then transferred to a dark bottle. This solution was stable for at least one week.

Sodium nitrite solution $\left(2.89 \times 10^{-3} \mathrm{M}\right)$. This solution was prepared by dissolving $0.0200 \mathrm{~g}$ of sodium nitrite in $100 \mathrm{ml}$ distilled water. Working solution $\left(7.9 \times 10^{-4} \mathrm{M}\right)$ of sodium nitrite was then prepared by diluting $27.3 \mathrm{ml}$ of the stock solution with distilled water in a $100 \mathrm{ml}$ volumetric flask.

HCl (1M) and NaOH (1M )solutions. These solutions were also prepared.

\section{Analytical Procedure for Calibration Curve}

An aliquot $0.05-2.0 \mathrm{ml}$ of a standard solution of SMX $\left(200 \mu \mathrm{g} / \mathrm{ml}=7.89 \times 10^{-4} \mathrm{M}\right)$ was transferred into a series of $25 \mathrm{ml}$ calibrated flasks. To each flask an equimolar of sodium nitrite solution $7.89 \times 10^{-4} \mathrm{M}$ was added and followed by $2 \mathrm{ml}$ of $1 \mathrm{M}$ hydrochloric acid solution and mixed thoroughly. After 3 minutes, $2 \mathrm{ml}$ of $0.1 \%$ 2,4,6-trihydroxybenzoic acid and $2 \mathrm{ml}$ of $1 \mathrm{M}$ sodium hydroxide solutions were added. The flasks were kept at room temperature $\left(25 \mathrm{C}^{\mathrm{o}} \pm 2\right)$ for 4 minutes and the contents were completed to the marks with distilled water and mixed well, then the absorbance of the product was measured at $416 \mathrm{~nm}$ against the corresponding reagent blank.

A linear relationship between absorption and SMX concentration in the range 10-400 $\mu \mathrm{g}$ of SMX $/ 25 \mathrm{ml}$ was obtained. The apparent molar absorptivity has been found to be $1.84 \times 10^{4} 1 . \mathrm{mol}^{-1}$. $\mathrm{cm}^{-1}$. Fig. (2).

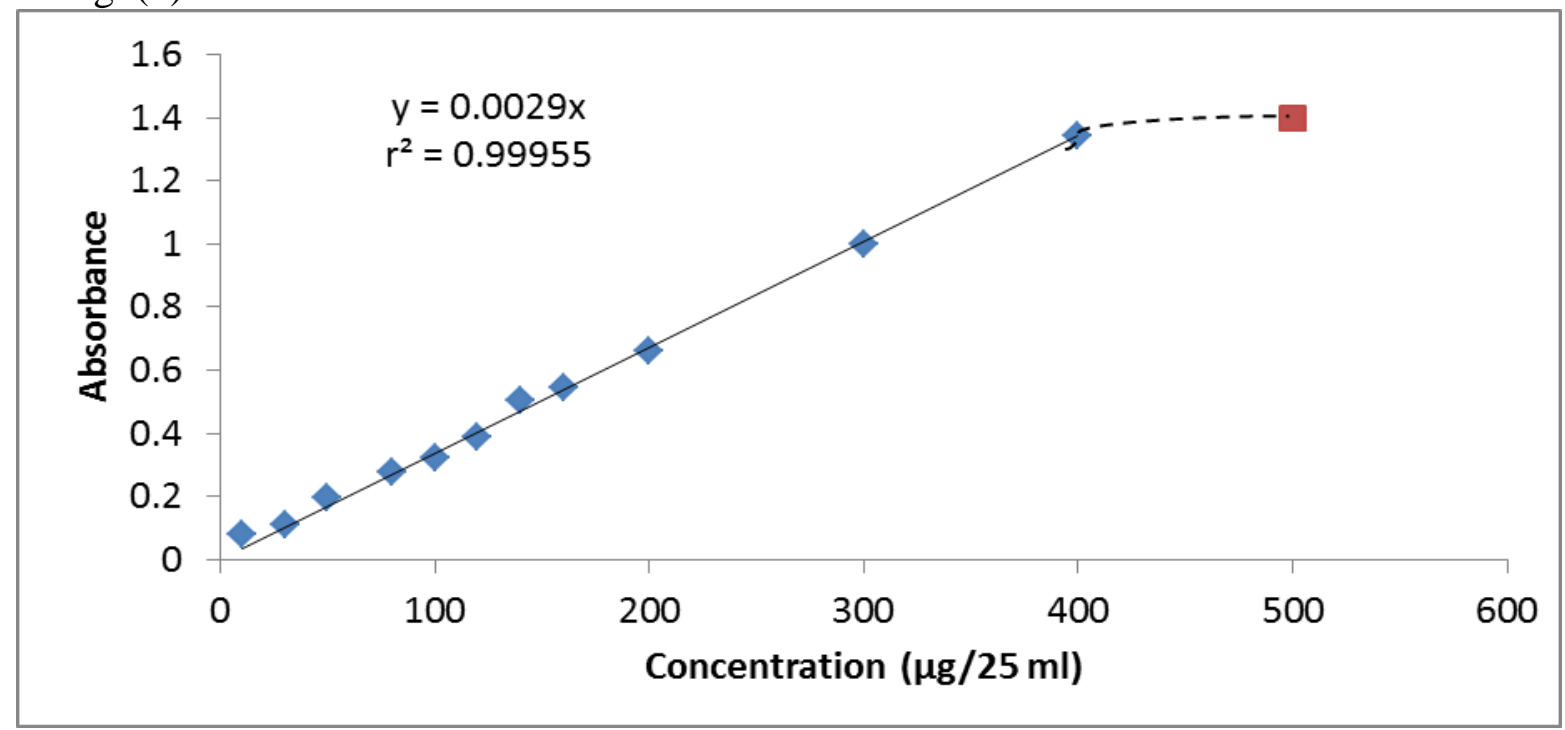

Fig. 2: The calibration curve for SMX determination 


\section{Procedure for the Assay of Pharmaceutical Preparations}

For tablets. Ten tablets (each containing $400 \mathrm{mg}$ SMX and $80 \mathrm{mg}$ TMP/ tablet) were weighed and crushed to powder. A portion of this powder, equivalent to $0.0500 \mathrm{~g}$ of SMX was weighed accurately and dissolved in $5 \mathrm{ml}$ of ethanol. The solution was mixed, warmed if necessary and filtered into a $100 \mathrm{ml}$ volumetric flask. The residue was then washed with $5 \mathrm{ml}$ of ethanol and the volume was diluted to the mark with distilled water. Each ml of this solution contains $500 \mu \mathrm{g}$ SMX. Working solution $\left(200 \mu \mathrm{g} / \mathrm{ml}=7.9 \times 10^{-4} \mathrm{M}\right)$ of SMX is prepared by diluting $40 \mathrm{ml}$ of the stock solution with distilled water into a $100 \mathrm{ml}$ volumetric flask. An aliquot of the diluted drug solution was then treated as done in a recommended procedure.

For oral suspension, (200 mg SMX and $40 \mathrm{mg}$ TMP $/ 5 \mathrm{ml}$ ). A suitable volume $1.25 \mathrm{ml}$ of the oral suspension containing about $0.05 \mathrm{~g}$ of SMX was diluted with $5 \mathrm{ml}$ of ethanol and a portion of distilled water. The solution was filtered into $100 \mathrm{ml}$ calibrated flask and the residue was washed with $5 \mathrm{ml}$ of ethanol and finally the volume was diluted to the mark with distilled water to obtain a solution contains $500 \mu \mathrm{g} / \mathrm{ml}$ of SMX . Working solution $\left(200 \mu \mathrm{g} / \mathrm{ml}=7.89 \times 10^{-4} \mathrm{M}\right)$ of SMX was prepared by diluting $40 \mathrm{ml}$ of the stock solution with distilled water into a $100 \mathrm{ml}$ calibrated flask. An aliquot of the diluted drug solution was then treated as done in a recommended procedure.

\section{Principle of the colour reaction}

\section{RESULTS AND DISCUSSION}

Under the reaction conditions, SMX was diazotized with equimolar of sodium nitrite solution $7.89 \times 10^{-4} \mathrm{M}$ in the presence of acid solution of $\mathrm{HCl}$ to give the diazonium salt. The diazonium salt was then reacted with 2,4,6-trihydroxybenzoic acid as a coupling agent in alkaline solution of $\mathrm{NaOH}$ to form a coloured azo dye . A reaction sequence is shown in Scheme (1) .
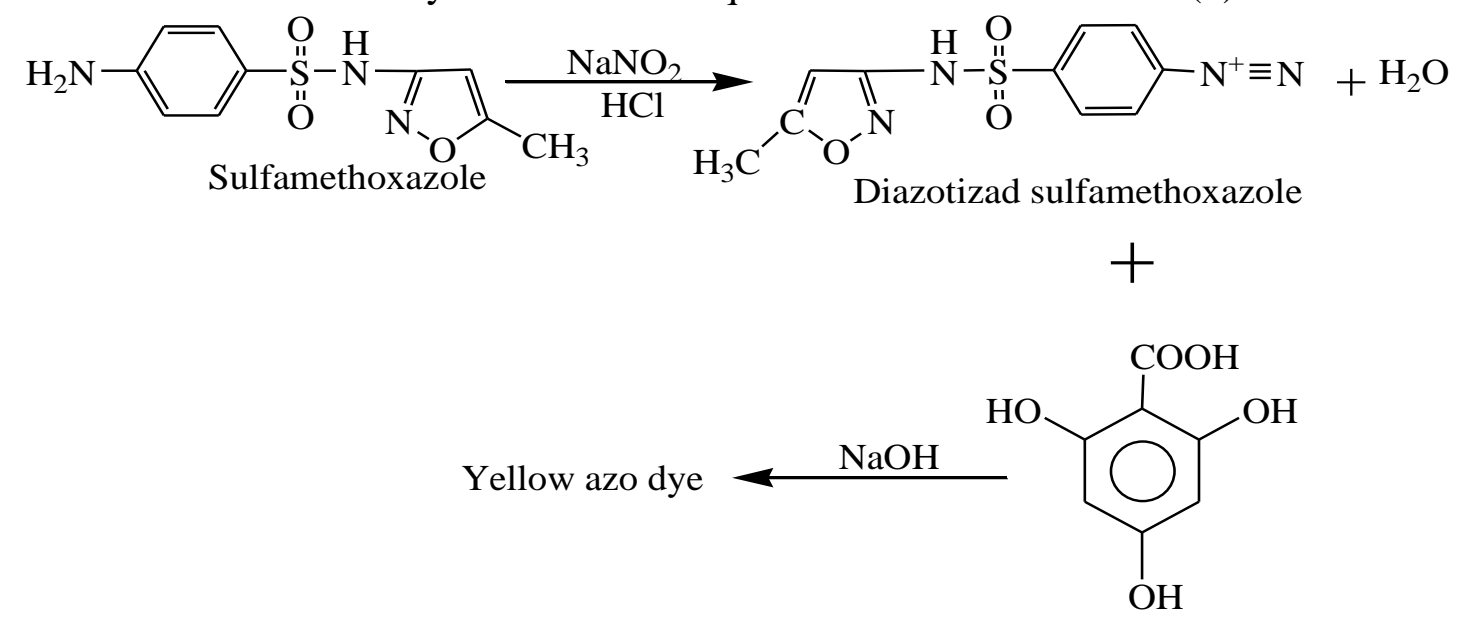

2,4,6-trihydroxybenzoic acid

\section{Scheme (1) reaction sequence}

Absorption maxima at $416 \mathrm{~nm}$ was exhibited due to formation of coloured azo dye. The formed coloured dye was exhibited maximum absorption at $416 \mathrm{~nm}$ against reagent blank solution. The intensity of the formed dye has been found to be proportional to the amount of SMX originally present in solution

\section{Optimum Reaction Conditions}

The effects of various parameters on the absorption intensity of the formed product were optimized. In the subsequent experiments, $1 \mathrm{ml}$ of SMZ solution $\left(200 \mu \mathrm{g} / \mathrm{ml}=7.89 \times 10^{-4} \mathrm{M}\right)$ with equimolar of sodium nitrite solution $\left(1 \mathrm{ml}\right.$ of $\left.7.89 \times 10^{-4} \mathrm{M}\right)$ was taken in $25 \mathrm{ml}$ final volume and mixed with $1.5 \mathrm{ml}$ of $1 \mathrm{M}$ hydrochloric acid, $1.5 \mathrm{ml}$ of 2,4,6-trihydroxy- benzoic acid $(0.1 \%)$ and 2 $\mathrm{ml}$ of $1 \mathrm{M}$ base and diluted to the mark with distilled water. The absorbance of solutions was measured at $416 \mathrm{~nm}$ versus reagent blank. This method does not need to get rid of excess sodium 
nitrite (by addition of sulfamic acid or ammonium sulfamate) because of the low concentration of sodium nitrite used in equimolar solution of SMX and sodium nitrite.

Effect of Diazotization Acid

The effects of various acids solutions (conc.=1M) such as, $\mathrm{HCl}, \mathrm{CH}_{3} \mathrm{COOH}, \mathrm{HNO}_{3}, \mathrm{H}_{2} \mathrm{SO}_{4}$ and $\mathrm{HCOOH}$ have been investigated in diazotization of SMX in order to produce intense coloured azo dye and lower blank value. The experimental investigations showed that $\mathrm{HCl}$ was the most suitable acidic medium for obtaining maximum absorbance and it was used in all subsequent experiments. The effect of different volumes $0.5-3 \mathrm{ml}$ of $1 \mathrm{M} \mathrm{HCl}$ has been examined on the maximum absorbance of the formed product. Fig. (3) shows that $2 \mathrm{ml}$ of $1 \mathrm{MHCl}$ were enough to obtain the maximum absorbance.

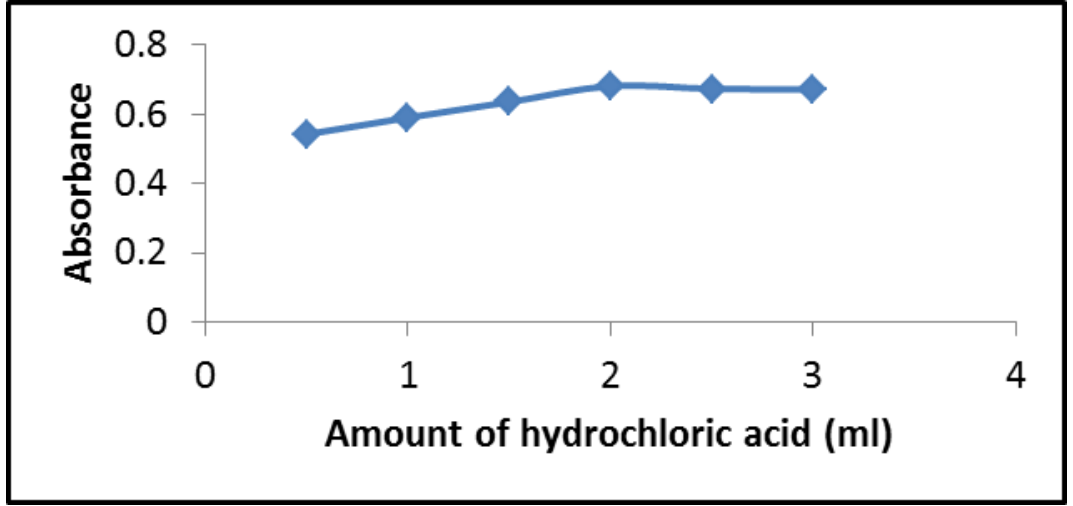

Fig. 3: Effect of the amount of 1M HCl on absorbance

The effect of temperature on diazotization was also studied. It was found that diazotization at 0-30 $\mathrm{C}^{\circ}$ gave maximum colour intensity. The experimental results showed that the effect of time for 2 minutes or more gave the same results, so 3 minutes was selected for studies gives maximum colour intensity.

\section{Effect of 2,4,6-Trihydroxybenzoic Acid Amount}

The influence of various amounts of 2,4,6-trihydroxybenzoic acid as a coupling reagent on the formation of azo dye was investigated. The results in (Table 1) indicated that $2 \mathrm{ml}$ of $0.1 \%$ 2,4,6trihydroxybenzoic acid are the more suitable to give high absorbance value for the azo dye and can be considered optimum.

Table 1: Effect of 2,4,6-trihydroxybenzoic acid amount on absorbance

\begin{tabular}{|c|c|c|c|c|c|c|}
\hline \multirow{2}{*}{\begin{tabular}{c} 
ml of $\begin{array}{c}\mathbf{0} \\
\text { reagent }\end{array}$ \\
\cline { 2 - 6 }
\end{tabular}} & $\mathbf{2 0}$ & $\mathbf{3 0}$ & $\mathbf{4 0}$ & $\mathbf{5 0}$ & $\mathbf{1 0 0}$ & \multirow{2}{*}{$\mathbf{r}^{\mathbf{2}}$} \\
\hline 0.5 & 0.065 & 0.103 & 0.119 & 0.166 & 0.239 & 0.97605 \\
\hline 1.0 & 0.083 & 0.115 & 0.124 & 0.182 & 0.267 & 0.98142 \\
\hline 1.5 & 0.097 & 0.129 & 0.144 & 0.195 & 0.281 & 0.98497 \\
\hline 2.0 & 0.103 & 0.139 & 0.171 & 0.201 & 0.385 & 0.99949 \\
\hline 2.5 & 0.098 & 0.111 & 0.145 & 0.176 & 0.289 & 0.99695 \\
\hline 3.0 & 0.087 & 0.102 & 0.123 & 0.149 & 0.245 & 0.99896 \\
\hline
\end{tabular}

The formation of azo dye was required 1 minute for complete colour development after addition of 2,4,6-trihydroxybenzoic acid. 


\section{Effect of Base}

The reaction of diazotized SMX with 2,4,6-trihydroxybenzoic acid was carried out in basic medium. Therefore, the effects of various alkaline solutions $($ conce $=1 \mathrm{M})$ were investigated such as, $\mathrm{NaOH}, \mathrm{NaCO}_{3}, \mathrm{KOH}$ and $\mathrm{NH}_{4} \mathrm{OH}$. The experimental investigations showed that the formation of the azo dye required a strong basic solutions of $\mathrm{NaOH}$ and $\mathrm{KOH}$. While $\mathrm{NaCO}_{3}$ and $\mathrm{NH}_{4} \mathrm{OH}$ exhibited weak colour contrast which is apparently due to $\mathrm{pH}$ variation. The most suitable basic solution to give maximum absorbance is $\mathrm{NaOH}$ solution and it was employed in all subsequent experiments. The effect of different amounts $0.5-3 \mathrm{ml}$ of $1 \mathrm{M} \mathrm{NaOH}$ has been investigated on the absorbance of the formed product. Fig. (4) shows that $2 \mathrm{ml}$ of $1 \mathrm{M} \mathrm{NaOH}$ are enough to obtain high sensitivity.

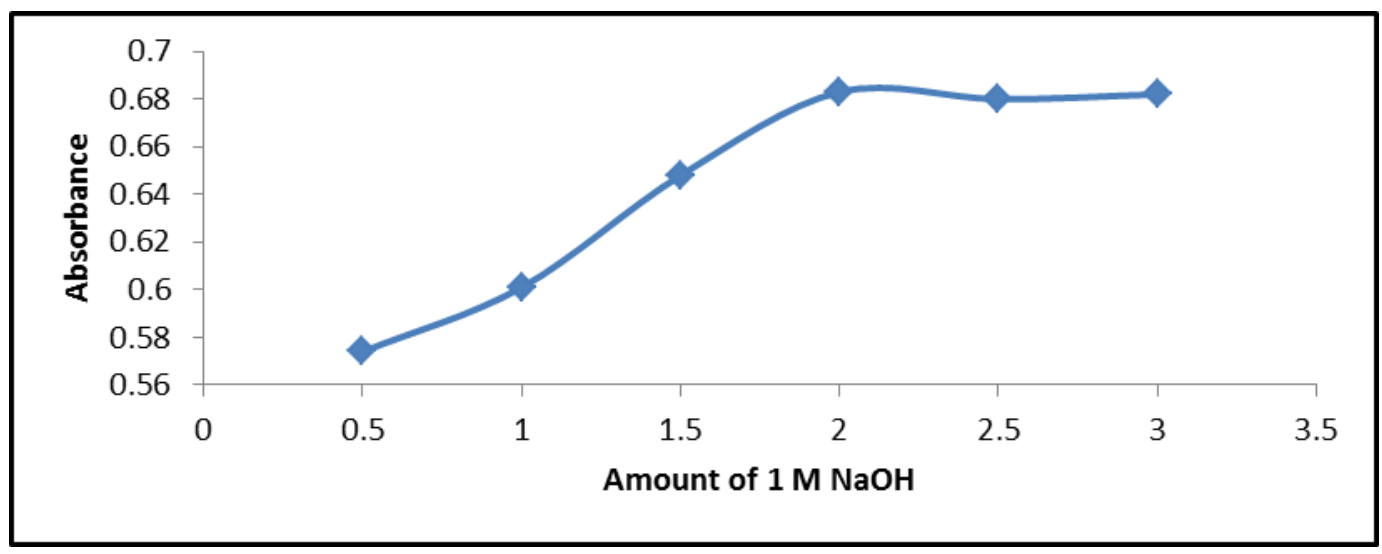

Fig. 4: Effect of the amount of $1 \mathrm{M}$ sodium hydroxide on absorbance.

\section{Effect of Time on Colour Development}

The effect of time on the stability of the coloured azo dye at $416 \mathrm{~nm}$ has been carried out by preparing two different amounts (50 and $200 \mu \mathrm{g}$ ) of SMX under the optimal experimental conditions, and the absorbance was measured at different time intervals up to 120 minutes. The results in Fig. (5) show that the absorbance reached maximum value after the reaction mixture solution was allowed to stand for 4 minutes and the absorbance remained maximum and constant for at least 120 minutes at room temperature.

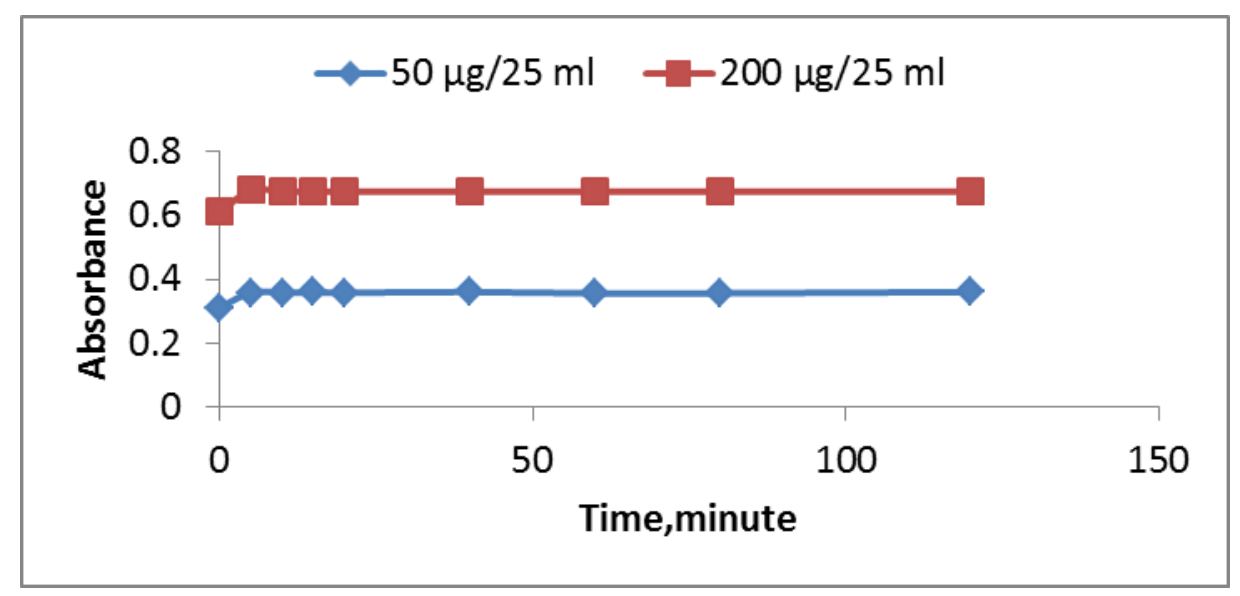

Fig. 5: Effect of time and amount of SMX on absorbance.

\section{Final Absorption Spectra}

Under the above optimized conditions, a yellow azo dye is formed by coupling of diazotized SMX with 2,4,6-trihydroxybenzoic acid in alkaline medium. This coloured dye exhibits maximum absorption at $416 \mathrm{~nm}$ against reagent blank as shown in Fig. (6). The corresponding reagent blank show a negligible absorbance at this wavelength. 


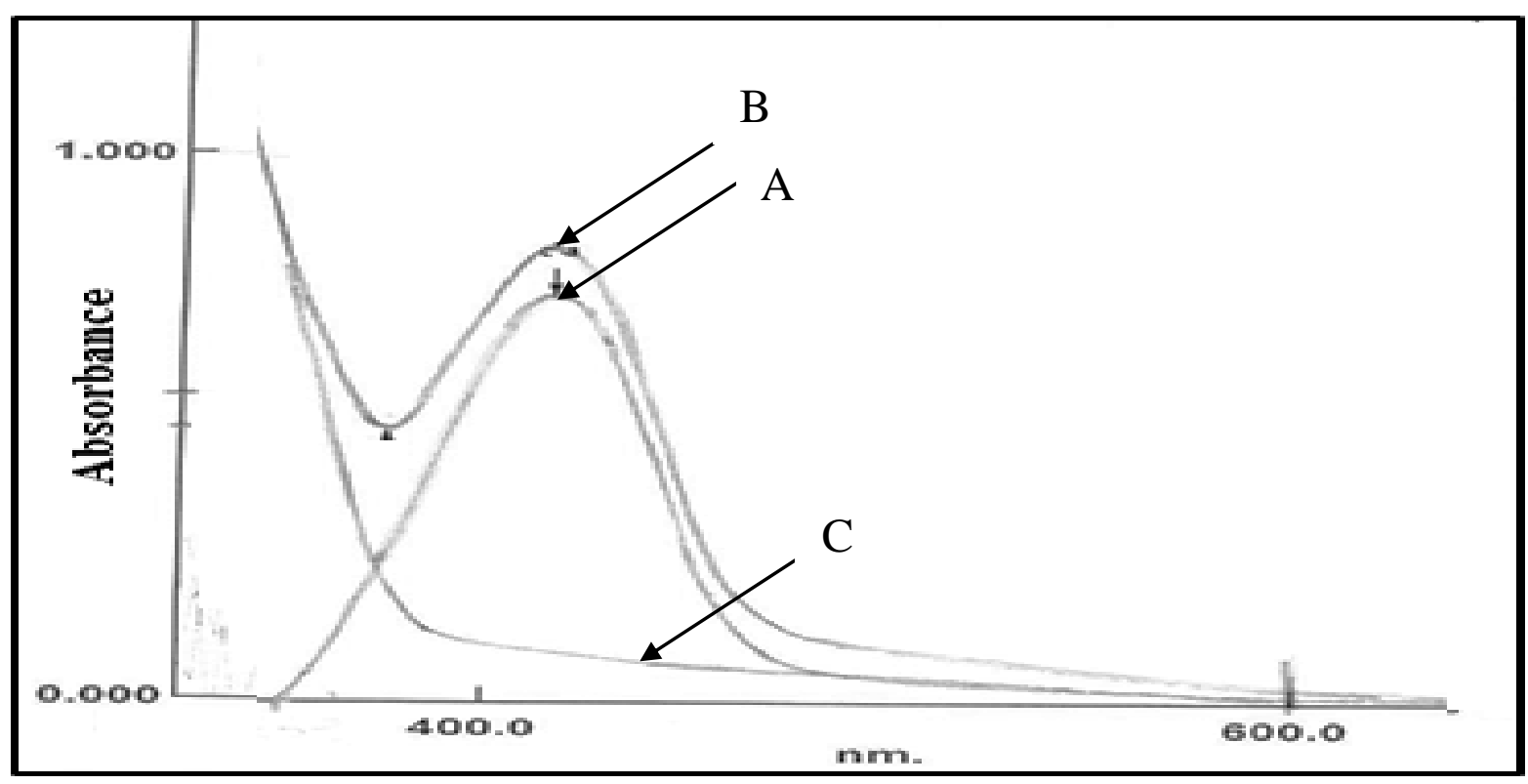

Fig. 6: Absorption spectra of (A) $\left(8 \mu \mathrm{g} \cdot \mathrm{ml}^{-1}\right)$ of SMX (A) SMX verses reagent blank, (B) $\left(8 \mu \mathrm{g} \cdot \mathrm{ml}^{-1}\right)$ of SMX verses distilled water, and (C) blank verses distilled water

\section{Accuracy and Precision}

The accuracy (recovery, \%) and precision (R.S.D, \%) of the proposed method were checked by analysis three different concentrations of SMX. The results in (Table 2) indicate that the method is satisfactory.

Table 2: Accuracy and precision of the method

\begin{tabular}{|c|c|c|c|c|}
\hline \multicolumn{2}{|c|}{ Amount of SMX $(\boldsymbol{\mu g} / \mathbf{m l})$} & \multirow{2}{*}{ Error $(\boldsymbol{\%})$} & \multirow{2}{*}{$\operatorname{Recovery}(\boldsymbol{\%}) *$} & \multirow{2}{*}{ R.S.D $(\boldsymbol{\%}) *$} \\
\cline { 1 - 2 } Present & Found & & 97.85 & \pm 0.23 \\
\hline 20 & 19.57 & -2.15 & 99.16 & \pm 0.23 \\
\hline 50 & 49.58 & -0.84 & 99.27 & \pm 0.12 \\
\hline 200 & 198.53 & -0.74 & 99.80 & \pm 0.06 \\
\hline
\end{tabular}

* Average of five determinations.

\section{Composition of azo dye}

The stoichiometry of the product was investigated using the mole ratio and continuous variation methods. In mole ratio method, increased volumes $0.5-6 \mathrm{ml}$ of $7.89 \times 10^{-4} \mathrm{M} 2,4,6-$ trihydroxybenzoic acid solution $\left(\mathrm{V}_{\mathrm{R}}\right)$ were added to a $2 \mathrm{ml}$ of $7.89 \times 10^{-4} \mathrm{M}$ of SMX $\left(\mathrm{V}_{\mathrm{S}}\right)$ which was diazotized by using $2 \mathrm{ml}$ of $7.89 \times 10^{-4} \mathrm{M}$ sodium nitrite in presence of $2 \mathrm{ml}$ of $1 \mathrm{M} \mathrm{HCl}, 2 \mathrm{ml}$ of $1 \mathrm{M} \mathrm{NaOH}$ was added and the absorbances were measured at $416 \mathrm{~nm}$ after dilution to the mark with distilled water. In continuous variation method, volumes $0.5-4.5 \mathrm{ml}$ of $7.89 \times 10^{-4} \mathrm{M}$ portions of $\mathrm{SMX}\left(\mathrm{V}_{\mathrm{S}}\right)$ were diazotized using equimolar of $7.89 \times 10^{-4} \mathrm{M}$ sodium nitrite and $2 \mathrm{ml}$ of $1 \mathrm{M} \mathrm{HCl}$ and coupled according to analytical procedure with the corresponding complementary volume of $7.89 \times 10^{-4} \mathrm{M}$ 2,4,6-trihydroxybenzoic acid solution $\left(\mathrm{V}_{\mathrm{R}}\right)$ to give a total volume of $5 \mathrm{ml}$ for $\mathrm{V}_{\mathrm{S}}+\mathrm{V}_{\mathrm{R}}$ in $2 \mathrm{ml}$ of $1 \mathrm{M} \mathrm{NaOH}$ and diluted to $25 \mathrm{ml}$ with distilled water. The results obtained in Fig.7 and Fig.8 show that a 1:1 azo dye is formed between diazotized SMX (S) and 2,4,6-trihydroxybenzoic acid (R).

For the diazotization reaction, it would be expected that $\mathrm{NH}_{2}$ group in $\mathrm{SMX}$ would be readily diazotized in $\mathrm{HCl}$ solution, and that diazonium ion would then react with a molecule of 2,4,6- 
trihydroxybenzoic acid by electrophilic substitution at the 4-position of the coupling agent to produce an intense yellow azo dye in sodium hydroxide medium.

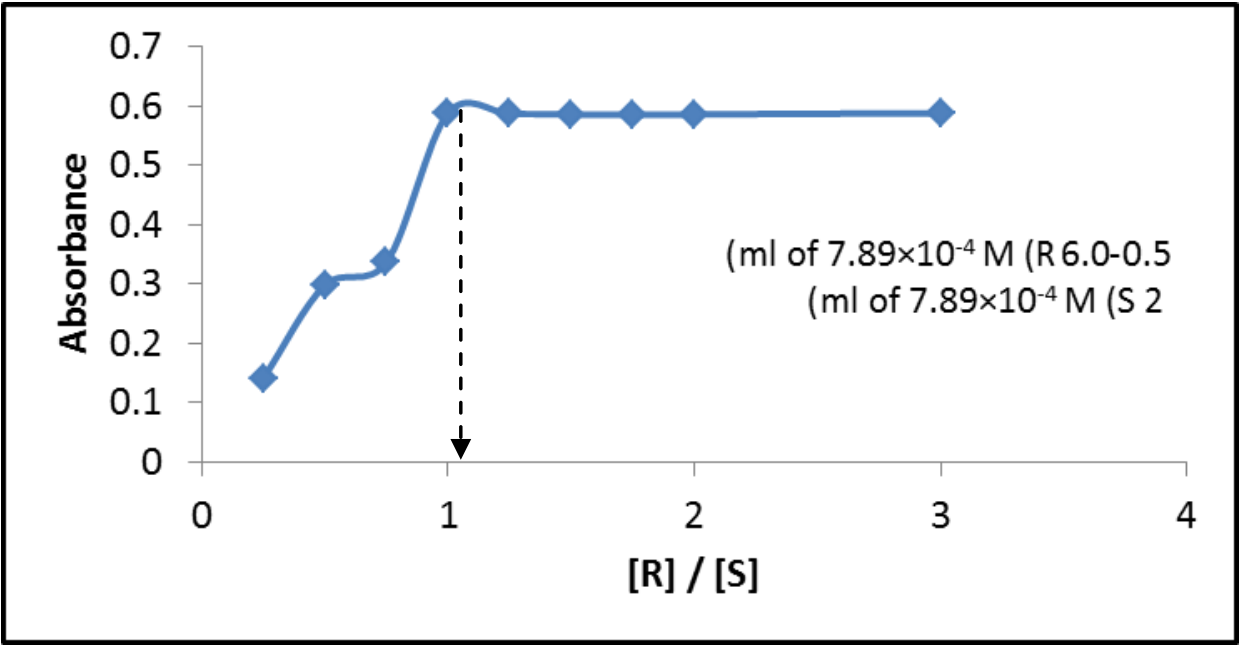

Fig. 7: Mole ratio plot

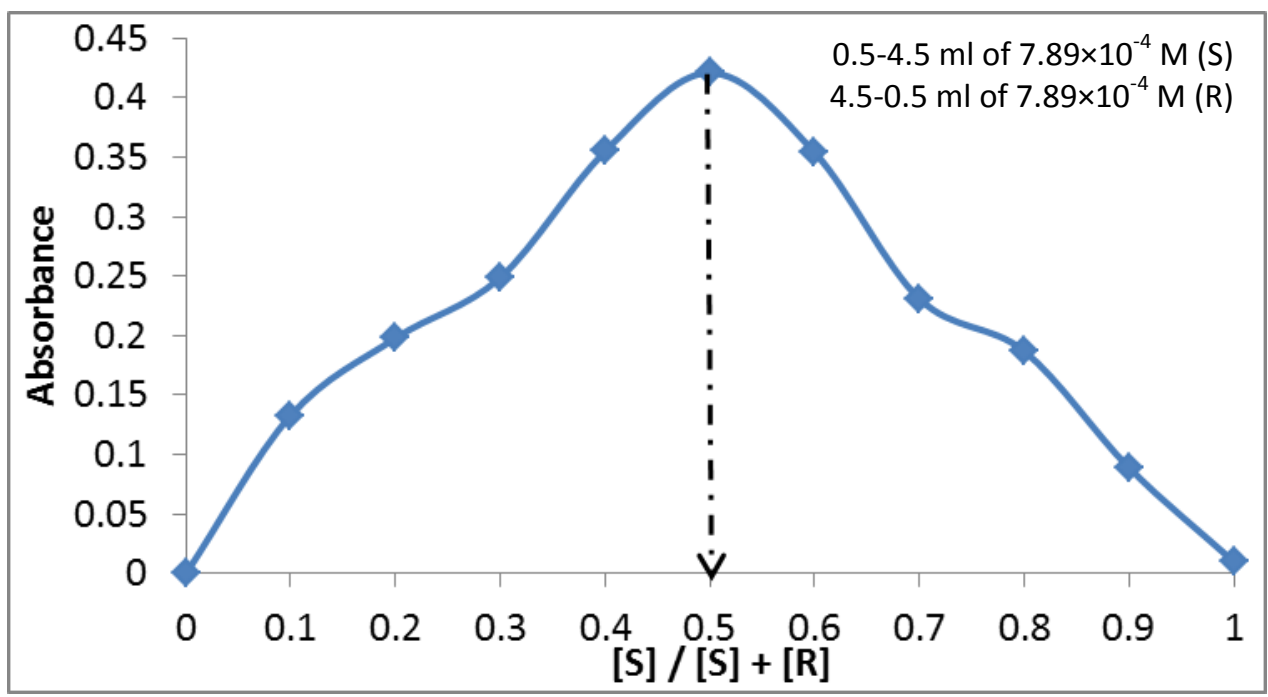

Fig. 8: Continuous variation plot

According to the results obtained in Fig. (7) and Fig. (8) The formation of the product azo dye can be written as follows Fig. (9):<smiles>Cc1cc(NS(=O)(=O)c2ccc(/N=N/c3c(O)cc(O)c(C(=O)O)c3O)cc2)no1</smiles>

Yellow azo dye

Fig. 9 : The composition of yellow azo dye 
The effect of some common excipients frequently found with SMX in dosage forms such as: glucose, starch, lactose, sucrose and trimethoprim was investigated by adding different amounts of excipient to $200 \mu \mathrm{g}$ of SMX. The results in (Table 3) indicate that there are no significant interferences produced by these excipients on the proposed procedure.

Table 3: Determination of SMX in the presence of excipients

\begin{tabular}{|c|c|c|c|}
\hline \multirow{2}{*}{ Excipients } & \multicolumn{3}{|c|}{ Recovery $(\boldsymbol{\%}) *$ of $\mathbf{2 0 0} \boldsymbol{\mu g} \mathbf{S M X} / \boldsymbol{\mu g}$ foreign compound added } \\
\hline & 100 & 250 & 500 \\
\hline Starch & 99.4 & 100.3 & 100.6 \\
\hline Glucose & 98.3 & 99.7 & 100.0 \\
\hline Lactose & 99.0 & 98.8 & 100.2 \\
\hline Sucrose & 101.9 & 101.6 & 102.2 \\
\hline Trimethoprim & 100.7 & 102.8 & 114.2 \\
\hline
\end{tabular}

* Average of five determinations

\section{Pharmaceutical Applications}

The proposed method was applied successfully to the analysis of SMX in various samples of dosage forms (tablets and suspensions) and the results were summarized in (Table 4). For all preparations examined, the assay results of proposed method are in good agreement with the declared content.

Table 4: Determination of SMX in pharmaceutical preparations

\begin{tabular}{|c|c|c|c|c|}
\hline $\begin{array}{l}\text { Pharmaceutical } \\
\text { preparation }\end{array}$ & $\begin{array}{c}\mu \mathrm{g} \text { SMX present } \\
\text { per } 25 \mathrm{ml}\end{array}$ & $\begin{array}{c}\mu \mathrm{g} \text { SMX found } \\
\text { per } 25 \mathrm{ml}\end{array}$ & $\begin{array}{c}\text { Relative error } \\
(\%)\end{array}$ & $\begin{array}{c}\text { Recovery } \\
(\%)^{*}\end{array}$ \\
\hline \multirow{3}{*}{$\begin{array}{c}\text { Methoprim tablet } \\
\text { (400 mg SMX and 80mg } \\
\text { TMP/tablet) (S.D.I.- Iraq) }\end{array}$} & 50 & 49.5 & -0.5 & 99.8 \\
\hline & 200 & 198.8 & -0.6 & 99.4 \\
\hline & 400 & 399.7 & -0.075 & 99.9 \\
\hline \multirow{3}{*}{$\begin{array}{c}\text { Ciplin tablet } \\
400 \text { mg /tablet } \\
\text { Cipla Ltd. (India) }\end{array}$} & 50 & 49.1 & -1.80 & 98.2 \\
\hline & 200 & 197.1 & -1.45 & 98.5 \\
\hline & 400 & 398.5 & -0.375 & 99.6 \\
\hline \multirow{3}{*}{$\begin{array}{c}\text { Balkatrin suspension } \\
200 \text { mg SMX/5ml } \\
\text { (Jordan) }\end{array}$} & 50 & 49.1 & -1.8 & 98.2 \\
\hline & 200 & 197.9 & -1.05 & 98.9 \\
\hline & 400 & 398.7 & -0.325 & 99.6 \\
\hline \multirow{3}{*}{$\begin{array}{l}\text { Trimoks suspension } 200 \\
\text { mg SMX/5ml (Turkia ) }\end{array}$} & 50 & 48.89 & -2.22 & 97.7 \\
\hline & 200 & 198.20 & -0.9 & 99.1 \\
\hline & 400 & 400.4 & 0.56 & 100.1 \\
\hline
\end{tabular}

* Average of three determinations.

\section{Evaluation of the Proposed Method}

According to the difficulties of using the standard method for determination of SMX in its pharmaceutical preparations, so that a standard addition method has been used for its simplicity which proves that the proposed method was applied successfully for the determination of SMX without interferences Fig. (10) and (Table 5). 


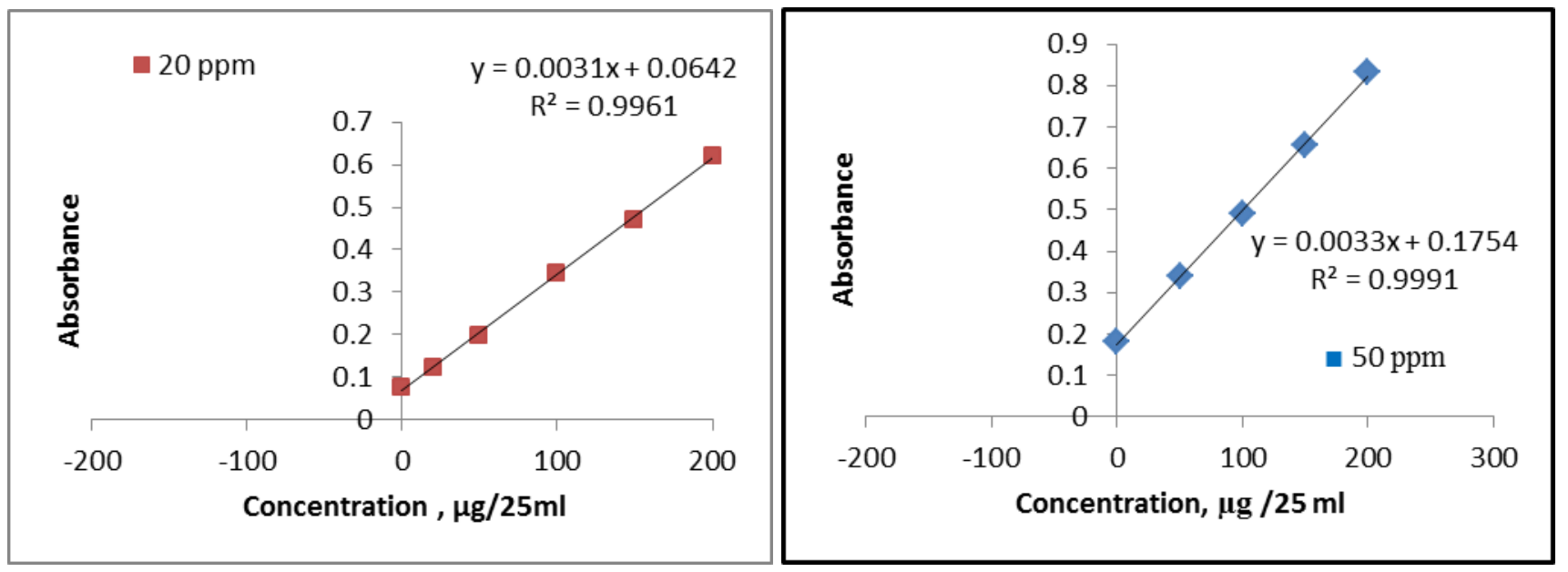

Fig. 10: Graphs of standard addition method of SMX in tablet, (Ciplin tablet)

Table 5: The results of standard addition method

\begin{tabular}{|c|c|c|c|}
\hline Pharmaceutical preparation & $\begin{array}{c}\text { SMX taken } \\
\boldsymbol{\mu g} / \mathbf{2 0} \mathbf{~ m l}\end{array}$ & $\begin{array}{c}\text { SMX measured } \\
\boldsymbol{\mu g} / \mathbf{2 0} \mathbf{~ m l}\end{array}$ & $\begin{array}{c}\text { Recovery, } \\
\mathbf{\%}\end{array}$ \\
\hline Ciplin (400 mg/tablet) Cipla Ltd. / India & 20 & 20.71 & 103.6 \\
\cline { 2 - 4 } & 50 & 53.15 & 106.3 \\
\hline
\end{tabular}

\section{CONCLUSION}

The proposed method offers clear advantages for the fast determination of SMX in the presence of the related compounds, such as TMP in pharmaceutical preparations. The method was found to be simple, economical, selective, sensitive, did not require the removal of excipients, temperature control, expensive reagents and organic solvents. It was also accurate, precise enough to be successfully adopted as an alternative to the existing spectrophotometric method and evaluation of SMX in both pure form and in its pharmaceutical preparations.

\section{REFERENCES}

Adegoke, O.A.; Babalola, C.P.; Kotila, O.A.; Obuebhor, O. (2017). Simultaneous spectrophotometric determination of trimethoprim and sulphamethoxazole following chargetransfer complexation with chloranilic acid. Arab. J. Chem., 10, S3848-S3860.

Andrade, L.S.; de Moraes, M.C.; Rocha-Filho, R.C.; Fatibello-Filho, O.; Filho Cass, Q.B. (2009). A multidimensional high performance liquid chromatography method coupled with amperometric detection using a boron-doped diamond electrode for the simultaneous determination of sulfamethoxazole and trimethoprim in bovine milk. Anal. Chim. Acta, 654(2), $127-132$.

Barragry, T.B. (1994). Chapter 12:"Sulfonamides in Veterinary Drug Therapy". Lea and Febiger, Philadelphia, Baltimore, Hong Kong, London, Munich, Sydney, Tokyo, Sayfa. pp. 297301.

Bedor, D.C.G.; Gonçalves, T.M.; Ferreira, M.L.L.; de Sousa, C.E.M.; Menezes, A.L.; Oliveira, E.J.; de Santana, D.P. (2008). Simultaneous determination of sulfam-ethoxazole and trimethoprim in biological fluids for high-throughput analysis: comparison of HPLC with ultraviolet and tandem mass spectrometric detection. J. Chromatogr., B 863(1), 46-54.

Boiko, M.; Vrublevska, T.; Korkuna, O.; Teslyar, G. (2011). Application of sulpha-nilamides disazo dyes with Tropaeolin $\mathrm{O}$ for simple, rapid and sensitive spectrophotometric assay of medicines. Spectroch. Acta. Part A: Molecular and Biomol. Spectro.,79 (2), 325-331.

Givianrad, M.H.; Saber-Tehrani, M.; Zarin, S. (2013). Genetic algorithm-based wavelength selection in multicomponent spectrophotometric determinations by partial least square 
regression: application to a sulphamethoxazole and trimethoprim mixture in bovine milk. J. Serb. Chem. Soc., 78(4), 555-564.

Hajian, R.; Haghighi, R.; Shams, N. (2010). Combination of ratio derivative spectro-photometry with simultaneous standard addition method for determination of sulphame-thoxazole and trimethoprim. Asian J. Chem., 22(8), 6569-6579.

Injac, R.J.; Katarina, K.R.; Strukelj, B. (2008). Optimal conditions for extraction and simultaneous determination of sulphamethoxazole and trimethoprim in pharmaceuticals by micellar electrokinetic capillary chromatography. J. Food. Drug Anal., 16(1), 18-25.

Joseph, R.; Kumar, K.G. (2010). Differential pulse voltammetric determination and catalytic oxidation of sulphamethoxazole using [5,10, 15,20-tetrakis(3-methoxy-4-hydroxy phenyl ) prophyrinato] $\mathrm{Cu}(\mathrm{II})$ modified carbon paste sensor. Drug Test and Analysis, 2(6), 278283.

Khalaf, H.S.; Al-Haidari, A.A.; Dikran, S.B.; Mohammed, A.K. (2014). Spectrophotometric determination of sulfamethoxazole following simple diazotization and coupling with diphenylamine. Ibn Al-Haitham J. Pure and Appl. Sci., 27(3), 365-380.

Khalaf, H.S.; Al-Haidari, A.A.; Dikran, S.B.; Mohammed, A.K. (2017). Spectrophotometric determination of sulfamethoxazole in pure and pharmaceutical preparations based on condensation reaction method. J. Babylon Univ. Pure and Appl. Sci., 25(2), 515- 524.

Mandel, G.L.; Petri, W.A. (2006). "Goodman and Gilman's the Pharmacological Basis of Therapeutics". $11^{\text {th }}$ ed., McGraw Hill, New York, $1057 \mathrm{p}$.

Mistri, H.N.; Jangid, A.G.; Pudage, A.; Shah, A.; Shrivastav, P.S. (2010). Simultaneous determination of sulfamethoxazole and trimethoprim in microgram quantities from low plasma volume by liquid chromatography-tandem mass spectrometry. Microchem. J., 94 (2), 130-138.

Mitscher, L.A. (2002). "Antibiotics and Antimicrobial Agents". in Foye's Principles of Medicinal Chemistry (William D.A.; Lemke T.L.), $5^{\text {th }}$ ed., New York, 819 p.

Mohammed, S.A.; Zamel, H.A. (2017). Spectrophotometric assay of sulphamethoxazole in pure and in pharmaceutical dosage forms by diazotization and coupling reaction. Raf. J. Sci., 26(6), $111-121$.

Nazer, M.A.K.; Shabeer, T.Kh.; Azuddin, P.R. (2001). Indirect potentiometric titration of sulphamethoxazole in the presence of trimethoprim in co-trimazole tablets using copper based mercury film electrode. Chem. Pharm. Bull., 49(3), 278-281.

Othman, N.S. (2005). Spectrophotometric determination of some sulfonamides in aqueous solution via azo-dye formation reaction. J. Educ. Sci., 17, 32-39.

Petri, W.A.; Jr. (2001). "Antimicrobial Agents, in Goodman and Gilman's Pharmacologi-cal Basis of Therapeutics". (Eds. J. G. Hardman and Lee E. Hill, New Limbird), 10 ${ }^{\text {th }}$ ed., McGraw York, pp. 1171-1188.

Qing-Cui, C.; Xiu-Hui, T.; Lian-Mei, J.; Wen-Jun, Z.; Jian-Nong, Y. (2008). Determination of effective ingredients in compound sulfamethoxazole tablets by capillary electrophoresis with amperometric detection. Chin. J. Anal. Chem., 36(3), 292-296.

Sabriye, P.O.; Yucel, S.; Guleren, A. (2011). Determination of sulphamethoxazole in pharmaceutical formulations by flow injection system/HPLC with potentiometric detection using polypyrrole electrode. J. Braz. Chem. Soc., 22(11), 2171-2177.

Shamsa, F.; Amani, L. (2006). Determination of sulphamethoxazole and trimethoprime in pharmaceuticals by Visible and UV spectrophotometry. Iran. J. Pharm. Res., 1, 31-36.

Siddappa, K.; Mahesh, T.; Mallikarjun, M.; Mallikarjun, K. (2011). Spectrophotometric methods for the determination of sulphamethoxazole by a Schiff's base reaction in pure and pharmaceutical dosage forms. J. Pharm. Res., 4(2), 308-391. 
Sinan, R.; Al-Uzri, W.A. (2011). Spectrophotometric method for determination of sulphamethoxazole in pharmaceutical preparations by diazotization-coupling reaction. $J$. Al-Nahrain Univ., 14(3), 9-16.

Souza , C.D.; Braga, O.C.; Vieira, I.C.(2008). Electroanalytical determination of sulfadiazine and sulphamethoxazole in pharmceuticals using a boron-doped diamond electrode. Sen. Actu. B: Chemical, 135(1), 66-73.

Upadhyay, K.; Asthana, A.; Tiwari, N.(2012). Solid Phase extractive spectrophotometric determination of some sulfa drugs. Asian J. Pharma. Clini. Res., 5(2), 222-226.

Vijaya, R.G.; Sekaran, C.B.; Kumari P.S.; Parveen S.K.; Mahesh P.V.S. (2008). Simple and rapid methods for the analysis of sulphonamide bacteriostatic antibiotic in dosage forms. Oriental J. Chem., 24(3), 1021-1024. 